Artikel Konseptual

\title{
KAMPUNG BATIK MANDING SIBERKREASI SEBAGAI MODEL PELESTARIAN PENDIDIKAN KARAKTER
}

\author{
Azi Wansaka1, Hernia Nur Hidayah², Hizma Arum Bakhittah \\ azi.wansaka.2016@student.uny.ac.id, hernianur.2018@student.uny.ac.id, \\ hizma.arum999@gmail.com \\ Prodi Ilmu Sejarah, Universitas Negeri Yogyakarta ${ }^{1}$ \\ Prodi Pendidikan IPS, Universitas Negeri Yogyakarta ${ }^{2}$ \\ Prodi Pendidikan Sosiologi, Universitas Negeri Yogyakarta ${ }^{3}$
}

\begin{abstract}
Batik is a series of mbat and tik. Mbat in Javanese is interpreted as ngembat or throw many times, whereas tik comes from the word titik. So, batik throwing dots repeatedly on the fabric. The points in batik are formed being a certain image will symbolize the character of the batik motif produced by every production house. This diverse batik motif is an illustration of how values are contained in the batik process. Perseverance, politeness, tenacity, and piety be the values contained in the batik process. However, nowadays it goes hand in hand over time the values contained in this batik process begin forgotten. This happens because of a lack of public understanding of the process batik. Kampung Batik Manding Siberkreasi is one form of preservation from community in Manding hamlet, Wonosari Gunung Kidul. Batik preservation this Wonosari community did this by establishing a Kampung Batik. In preservation is also taught in relation to the values contained within batik process, starting from the process of making motifs to coloring. These values are contained in this batik which can be a reference for character
\end{abstract}

Key words: Education, Character, Batik

\section{PENDAHULUAN}

Batik merupakan salah satu kebudayaan nasional Indonesia yang saat ini terus mengalami perkembangan sejak zaman kerajaan hingga zaman modern. Perkembangan yang terjadi pada batik dapat meliputi proses pembuatannya, fungsi hingga ragam motif dan pola. Hal ini mengingatkan kepada kita bahwa batik batik yang ada sekarang merupakan manifestasi dari batik-batik terdahulu.

Secara etimologi, kata batik berasal dari bahasa Jawa, "amba" yang berarti lebar, luas, kain; dan "titik" yang berarti titik atau matik (kata kerja membuat titik) yang kemudian berkembang menjadi istilah (kata kerja membuat titik) yang kemudian berkembang menjadi istilah "batik", yang berarti menghubungkan titik-titik menjadi gambar tertentu pada kain yang luas atau lebar. Batik juga mempunyai pengertian segala 
sesuatu yang berhubungan dengan membuat titik-titik tertentu pada kain mori.(Batik Nusantara: Makna filosofi, cara pembuatan \& industri batik hal: 4).

Secara umum batik dapat diartikan sebagai kain yang memiliki motif-motif dan warna tertentu. Secara luas batik dapat diartikan juga sebagai serangkaian proses atau teknik penggambaran motif hingga pelorodan. Proses didalam batik inilah yang menjadi bagian-bagian penting dan asal-usul dari penyebutan istilah batik.

Pada masa lalu batik merupakan kain khusus yang hanya boleh dipakai oleh kalangan tertentu, yaitu golongan kerajaan. Pemakaian ini pun dilakukan dengan aturan yang ketat. Pembatasan pemakaian ini tentu saja dengan maksud dan tujuan tertentu. Namun dalam perkembagannya batik ini sudah menjadi pakaian nasional sehingga dapat dipakai oleh semua kalangan. Awal penggunaan batik adalah untuk menghias daun lontar yang berisi naskah agar tampilannya lebih indah. Namun, seiring perjalanan jaman dan semakin kompleksnya interaksi masyarakat Indonesia dengan orang asing maka media membatik berganti menjadi kain.

Berdasarkan catatan Pires, pada awal abad ke-16, Banda sudah mengimpor kain dan tenunan halus dari negeri-negeri Asia disebalah barat yang dibawa oleh kapal-kapal Portugis. Menurutnya, pedagang-pedagang kecil dari Jawa dan Melayu dating mebawa tenunan kasar. Namun, Raja Gresik juga sering memborong kain-kain halus dan sutra yang dimasukkan ke badarnya dengan maksud untuk diekspor lagi ke Banda dan tempat lain di Maluku. Disini, kain halus tersebut tidak hanya diperlukan sebagai pakain raja dan keluarganya serta kaum bangsawan lain, tetapi disimpan sebagai barang berharga barang lain (Lapian, 2017).

Pada masa kini kita dapat menemukan berbagai macam jenis batik, baik batik tulis, cap, bahkan printing. Harga jenis-jenis batik ini pun beragam dimulai dari puluhan ribu rupiah hingga jutaan rupiah. Semakin tinggi tingkat kesulitan dalam proses pembuatan batik maka semakin tinggi pula lah harganya. hal inilah yang membuat batik sebagai pakaian yang sangat sering dipakai oleh masyarakat luas baik para pejabat maupun rakyat biasa. Karena memang selain enak dipakai tentu juga harganya yang beragam.

Batik sebagai salah satu karya seni budaya bangsa Indonesia telah mengalami perkembangan seiring dengan perjalanan waktu. Perkembangan yang terjadi membuktikan bahwa batik sangat dinamis dapat menyesuaikan dirinya baik dalam dimensi ruang, waktu, dan bentuk ( Parmono, 2013). Perkembangan ruang yang dimaksud adalah berupa persebaran batik yang ada di nusantara, seperti daerah Solo, Yogykarta, Cirebon, maupun kawasan di luar pulau Jawa. Menurut dimensi waktu batik yang ada merupakan perkembangan dari batik-batik yang sudah ada sebelumnya. Seperti motif batik yang modern yang merupakan perkembangan motif batik yang sudah ada sebelumnya. Sedangkan menurut dimensi bentuk, batik yang berkembang sekarang selalu mengalami JPSI, Vol. 2, No., 2, 2019 
perubahan bentuk. Hal ini karena perkembangan zaman yang semakin berubah. Semakin banyak perubahan maka akan semakin banyak perubahan, pola dan bentuk yang ada. Contohnya adalah motif-motif batik modern yang ada saat ini.

Perkembangan batik yang semakin pesat ini dapat memberikan dampak yang baik bagi kebudayaan nasional Indonesia. Namun, dampak negatif pun menyertai perkembangannya. Modifikasi dalam proses pembuatan batik membuat jumlah produksi batik meningkat pesat. Ditambah dengan adanya teknik printing, jumlah batik yang pada awalnya hanya bisa diproduksi satu bulan satu buah kini dapat dibuat ratusan hanya dalam waktu satu hari. Hal inilah yang menyebabkan industri batik tulis semakin kurang diminati oleh pembuat batik pada masa kini.

Kebudayaan memiliki sifat dinamis atau selalu berubah-ubah. Tidak ada kebudayaan yang tidak mengalami perubahan secara mutlak, artinya bagaimanapun keadaan kebudayaan selalu mengalami perubahan (Darini, 2013). Hal ini memebrikan fakta bagi diri kita bahwa batik akan selalu memiliki perbedaan dari masa ke masa, baik jika kita lihat dari cara pengolahan atau pun motif yang dihasilkan.

Dengan hilangnya proses pembuatan batik ini nilai-nilai yang terkandung dalam prosesnya pun ikut hilang. Padahal proses dalam pembuatan batik memiliki nilai-nilai dan makna yang penting di dalamnya. Hal inilah yang seringkali dilewatkan oleh masyarakat secara umum. Sehigga masyarakat secara umum hanya megetahui batik sebatas kain yang bermotif. padahal dalam batik ini sendiri memiliki nilai-nilai tersendiri. Nilai-nilai ini seharusnya mampu menjadi pedoman masyarakat dalam kehidupan sehari-harinya.

\section{ASAL USUL BATIK}

Batik sendiri pada awalnya merupakan suatu kain dengan motif yang berasal dari tanah Jawa. Awal mula kemunculannya tidak dapat kita pisahkan dari adanya kerajaan Majapahit di Jawa. Batik pada masa itu dijadikan sebagai hiasan pada daun lontar, bukan sebagai pakaian tradisional. Pola atau motif batik yang terdapat pada daun lontar itu didominasi oleh bentuk hewan dan tumbuhan. Baru setelah melalui berbagai perkembangan motif yang dihasilkan lebih beragam seperti motif awan, relief candi, wayang, dan lain-lain. Hal ini memberikan gambaran bagi kita bahwa batik selalu mengalami perkembanga dari masa ke masa.

Perkembangan batik selalu identik dengan letak geografis dari terciptanya batik tersebut. Salah satu contohnya dalah batik Kendal yang memiliki tiga motif yaitu, motif pesisir, dataran rendah, dan dataran tinggi. Motif-motif ini pun memiliki ciri khas 
tersendiri seperti motif pesisir yang cenderung bermotif binatang laut, motif dataran rendah yang bercorak binatang, tumbuhan, ataupun benda-benda di daerah dataran rendah. Sedangkan batik dataran tinggi lebih bercorak binatang-binatang atau tumbuhan yang khas dari daerah pegunungan ( Prasetyo, 2016).

Wajah batik Nusantara terbentuk bukan saja dari budaya internal suku-suku yang hidup di kawasan negeri kita saja, tetapi juga akibat berbagai keterlibatan bangsa lain. Di antaranya pengaruh budaya bangsa Cina, India, Arab, hingga kedatangan bangsa-bangsa Eropa khususnya pada masa penjajahan Belanda dalam kurun waktu yang panjang dan diakhiri penduduk Jepang yang sekalipun dalam waktu yang tidak terlalu panjang, namun sempat menorehkan pengaruh yang cukup berbekas hingga kini (Kusrianto, 2013)

Seni batik, khususnya di daerah Keraton Yogyakarta dan Keraton Surakarta, dipengaruhi oleh budaya Hindu. Dahulu, salah satu aspek fungsi penggunaan motif batik adalah sebagai media untuk mengatur kehidupan sosial dalam masyarakat yang berkaitan dengan pembagian strata social (Paeni, 2009). Batik-batik yang dianggap terlarang untuk dipakai oleh masyarakat umum itu terdiri dari motif Sawat, Parang Rusak, Cemukiran, Udan Liris, Rujak Sante, Garuda Ageng, Kawung, dan Semen.

Perkembangan batik sebagai pakaian tradisional berdampak pada semakin beragamnya bentuk dan pola. Pola yang berkembang ini memiliki ciri khas tersediri terutama yang berada di kawasan keraton dan luar keraton yang sering disebut juga batik pesisir. Selain dari kedua jenis batik tersebut juga ada batik pedalaman yang memiliki pola motif dan bentuk khas yang berbeda. Sehingga untuk memahaminya batik di Nusantara itu dapat kita bagi ke dalam tiga golongan besar yaitu sebagai berikut:

\section{Batik Keraton}

Batik ini merupakan batik yang berkembang di kalangan Keraton, misalnya Keraton Yogyakarta dan Keraton Solo. Ciri khas yang mendominasi pada batik ini terletak pada hiasan yang bersifat simbolis, berlatar budaya Hindu, Budha dan Islam. Selain itu batik yang berkembang di wilayah ini biasanya memiliki warna-warna yang cenderung netral dan kalem seperti soga(merah), indigo(biru), hitam, cokelat, dan putih.

Sulit dingkari, bahwa puncak kemegahan seni batik Nusantara adalah pada batik yang dikembangkan di Kesultanan Surakarta (Surakarto Hadiningrat) yang kemudian akan sering kita sebut dengan Solo, dan Yogyakarta (Ngayogyokorto Hadiningrat) yang kemudian akan sering kita sebut Yogya. Batik solo dan Yogya dikenal sebagai batik yang dalam istilah bahasa Belanda juga disebut dengan "Vorsenlanden". Secara harfiah istilah ini berarti "wilayah-wilayah kerajaan", yaitu Kesultanan Surakarta dan Yogyakarta. Kedua daerah ini merupakan wilayah kekuasaan empat kerajaan ("Catur Sagatra") yang menjadi penerus dinasti Mataram (Adi, 2013). 


\section{Batik pesisir}

Batik pesisiran adalah batik yang berkembang di kawasan Pantai Utara Pulau Jawa. Kemunculannya dengan membawa ciri yang sangat kuat membuat para pengamat batik di zaman penduduk Belanda dengan tegas mengelompokkan batik Jawa menjadi dua, yaitu batik Vorstenlanden dan batik Pesisiran.(Batik filosofi) Stigma zaman Belanda yang mengklasifikasikan batik menjadi dua jenis ini merupakan hal yang wajar pada masa itu. Sehingga ketika kain batik tidak masuk kedalam dua jenis batik tersebut maka kain tersebut dianggap bukan kain.

Ciri batik di kawasan pesisir ini sangat identik dengan ragam hias yang natural dan banyak dipengaruhi oleh oleh bangsa asing. Hal ini disebabkan karena kawasan pantai atau pesisir yang ramai dikunjungi oleh pedagang dari berbagai daerah. Ragam warna yang diampilkan pada batik pesisir pun tampil lebih berani dan mencolok.

Motif batik yang terkadang dianggap nyeleneh dan mempunyai warna serta motif yang berbeda dengan batik keraton. Hal membuat batik ini pada awalnya dianggap sebagai pemberontakan terhadap batik keraton yang terkesan kaku dan berpedoman pada pake yang ada. Jadilah batik ini sebagai batik pesisir yang dianggap lebih baru dan modern.

\section{Batik Pedalaman}

Batik yang berkembang di daerah Bali, Lampung, dan Abepura merupakan batik yang memiliki motif, corak, dan ragam hiasan yang sama sekali berbeda dengan batik keraton dan batik pesisir. Batik pedalaman sangat eksis di daerahnya masing-masing tetapi sering dianggap bukan sebagai batik. Hal ini karena batik pedalaman dianggap sebagai batik yang keluar dari pakem(aturan) batik. Walaupun dari sisi prosesnya sama dengan batik pada umumnya. Walaupun seperti itu keberadaan batik pedalaman telah turut serta mewarnai perkembangan batik di Nusantara.

Batik-batik ini terutama berkembang di luar Jawa dengan mengutamaknunsur-unsur local yang kental. Ciri unik ini dipengaruhi oleh unsur-unsur daerah yang berbeda dengan ciri umum di Jawa maupun pesisiran (Kusrianto, 2011). Batik-batik pedalaman yang dimaksud ini merupakan perkembangan batik yang terlepas dari unsur keraton maupun batik pesisir. Pola yang digunakan lebih kepada penekanan unsur-unsur yang ada di daerah asal mereka untuk mewarnai corak dan ciri khas kain yang dibuatnya.

Ketiga jenis batik tadilah yang tersebar di seluruh kepulauan yang ada di Indonesia. Setiap daerah penghasil batik menciptakan motif, corak, dan ragam hiasnya tersendiri yang memiliki makna dan arti tersendiri. Setiap lekukan dan warna yang terdapat pada kain batik mempunyai makna yang terkandung di dalamnya. Biasanya makna yang terkandung menjadi gambaran lingkungan sekitar dari daerah lahirnya batik tersebut. 
Makna yang terkandung di dalam batik seharusnya mampu menjadi pembelajaran dan sarana edukasi bagi masyarakat secara umum. Baik yang masih usia dini maupun yang sudahlanjut usia. Proses batik yang panjang memberikan gambara kepada kita pentingnya kesabaran untuk membuat hasil yang maksimal. Selain itu motif batik yang beragam memberikan gambaran kepada kita bahwa motif batik yang dihasilkan tak lepas dari nilai-nilai yang ada pada masyarakat. Hal ini mengindikasikan kepada kita bahwa bangsa Indoensia adalah bangsa yang menjunjung tinggi nilai-nilai di dalam kehidupannya.

Pada masa kini perkembangan batik sudah berbeda dengan masa-masa kerajaan. Jika batik pada masa kerajaan cenderung tersebar hanya pada kalangan keraton maka pada masa kini batik cenderung dijual secara bebas bahkan sampai menjadi pakaian nasional yang dapat dipakai oleh siapa pun baik masyarakat menengah atas maupun menengah kebawah. Pada akhirnya untuk kepentingan pendidikan dan pewarisan budaya pada tanggal 2 Oktober 2009 UNESCO menetapkan batik sebagai warisan budaya dunia yang berasal dari Indonesia. Sejak itulah, tanggal 2 Oktober diperingati sebagai "Hari Batik" di Indonesia (Kusrianto, 2011). Hal ini membuktikan kepada kita bahwa batik sudah menjadi budaya Indonesia yang sudah mendapatkan pengakuan dunia Internasional.

Batik yang cenderung terjual bebas ini juga didukung oleh industri batik di berbagai daerah terutama Solo dan Yogyakarta. Sehingga tak heran di kedua daerah ini banyak berkembang kampung-kampung batik yang memproduksi batik khas daerahnya sendiri. Batik yang dihasilkan oleh kampung-kampung batik ini pun beragam, entah itu batik tulis, cetak atau printing.

Apalagi dengan berbagai perkembangan zaman yang sedemikian cepat dan teknologi yang semakin maju membuat membuat banyak motif-motif batik yang terinspirasi dari perkembangan teknolgi tersebut. Hal inilah yang membuat batik hingga saat ini tak pernah hilang dimakan zaman. Karena selalu megikuti perkembangan zaman. Motif-motif yang dihasilkan pun terkadang tidak hanya diterapkan dalam kain namun juga pada benda-benda lain seperti sepatuh, tas, ikat pinggang bahkan barang-barang mewah seperti mobil.

Industri batik terus mengalami perkembangan seiring dengan pengukuhannya sebagai pakaian nasional Indonesia. Busana batik kini telah berubah menjadi busana nasional Indonesia sebagai pengganti jas pada acara-acara tertentu. Hal ini dilandasi pemikiran-pemikiran sebagai berikut:

1. Suasana kemerdekaan yang menggugah semangat persatuan di seluruh bidang kehidupan masyarakat. 
2. Batik dapat menampilkan nilai seni budaya sebagai jati diri bangsa sekaligus menyuarakan pesan persatuan Indonesia, dengan tujuan agar batik tidak hanya dikenal sebagai batik dari daerah di Indonesia, tetapi juga mencerminkan persatuan Indonesia.

3. Mendorong semangat para seniman batik daerah untuk berkarya sekaligus menumbuhkembangkan rasa memiliki warisan budaya leluhur pada seluruh bangsa Indonesia.

4. Sebagai bahan sandang tradisional yang memiliki kekhasan tersendiri, batik memungkinkan dijadikan busana nasional Indonesia.

Namun, ditengah perkembangan batik yang semakin pesat membuat banyak batik yang berkembang membuat banyak cara pembuatan batik yang berkembang semakin beragam. Metode printing yang cenderung bisa meghasilkan banyak kain batik. Disatu sisi hal ini tentu memberikan dampak positiv dengan semakin banyaknya jumlah kain yang dihasilkan. Namun, disisi yang lain perkembangan metode pembuatan batik yang cepat ini membuat matinya industri batik tradisional seperti batik tulis dan batik cap. Untuk mengatasi hal inilah di Dusun Kepek, Wonosari, Gunungkidul lahir sebuah kampung batik yang bernama Kampung Batik Manding Siberkreasi.

\section{KAMPUNG BATIK MANDING}

Kampung Batik Manding Siberkreasi adalah sebuah kampung batik yang terletak di dusun Kepek 01, Wonosari, Gunungkidul. Pendirian kampung ini tidak bisa kita lepaskan dari peran serta salah seorang warga kampung tersebut yaitu Pak Guntur dan istri. Sepasang suami istri ini merintis usaha pembuatan batik sudah sejak lama. Berkat usaha dan ketekunan mereka akhirnya warga sekitar pun turut serta dalam proses pendirian kampung batik tersebut.

Kampung Batik Manding yang pada awalnya disebut sebagai dusun Kepek 1 itu bukan merupakan kawasan pembuat batik. Warga yang tinggal dikawasan tersebut kebayakan berasal dari pegawai negeri sipil. Awal mula munculnya Kampung Batik tersebut berasal dari usaha-usaha yang dilakukan warga sekitar untuk melestarikan kerajinan batik di masyarakat. Usaha itu dilakukan dengan cara mengajarkan bagaimana proses pembuatan batik itu sendiri dilakukan. Batik yang sudah berhasil dibuat kemudian dipasarkan.

Kampung batik Manding Siberkreasi ini pertama kali diresmikan pada Oktober 2018 silam. Peresmian tersebut dipimpin oleh Kementerian Komunikasi dan Informasi Indonesia (KOMINFO). Harapannya dengan diresmikannya Kampung Batik Manding Siberkreasi ini dapat mampu menjadi pelestari batik yanga ada di Yogyakarta. 
Kampung Batik Manding ini sendiri setidaknya sudah memiliki sekitar 12 kios toko yang menjual batik khas. Selain adanya kios-kios tersebut, Pak Guntur dan istri selaku tokoh yang berperan penting dalam menginisiasi kampung batik ini juga turut aktif dalam pembinaan di desa-desa di Gunungkidul. Setidaknya ada sekitar 3 desa yang juga dibina oleh Pak Guntur selaku inisiator Kampung Batik Manding Siberkreasi.

Salah satu hal yang membedakan antara kampung batik ini dengan kampung batik di daerah lainnya adalah terletak pada bangunan-bangunan warga yang ikut di cat sesuai dengan pola motif batik. Hal ini dilakukan dengan tujuan agar generasi muda terutama yang masih usia dini sudah dikenalkan dengan batik. Sehingga nantinya tidak akan asing lagi terhadap batik. Selain itu, anak-anak juga diharapkan dapat memahami tentang pentingnya nilai-nilai yang terkandung di dalam batik.

Pola pendidikan yang diajarkan di Kampung Batik ini adalah memberikan keteladanan bagi anak usia dini untuk bias melihat kebiasaan orang dewasa sehari-hari. Pola pendidikan seperti ini merupakan pola yang dapat merangsang kesadaran dan pemahaman anak betapa pentingnya batik sebagai kebudayaan nasional Indonesia.

\section{BATIK SEBAGAI PENDIDIKAN KARAKTER}

Pendidikan karakter merupakan suatu gerakan bersama dan disengaja untuk menciptakan ekosistem pendidikan yang ramah secara moral (Koesoema, 2017). secara umum pernyataan ini dapat diartikan bahwa tujuan pendidikan karakter adalah bukan hanya untuk membentuk pribadi manusia yang memiliki karakter dewasa dan bertanggung jawab, namun juga sebagai usaha-usaha yang dilakukan untuk membentuk suatu lingkungan dan ekosistem yang mampu membelajarkan individu untuk dapat memiliki karakter yang dewasa dan bertanggung jawab.

Ada enam karakter utama yang dapat dikatakan sebagai pilar-pilar karakter manusia, keenam pilar tersebut adalah sebagai berikut (Fatchul, 2011).

1. Respect (penghormatan)

2. Responsibility(tanggung jawab)

3. Citizenship-Sivic Duty (kesadaran berwarga-negara)

4. Fairness (keadilan dan kejujuran)

5. Caring (kepedulian dan kemauan berbagi)

6. Trustworthiness (kepercayaan)

Ekosistem yang baik akan membantu menumbuhkan kedewasaan moral dan melahirkan individu-individu yang mampu bertanggung jawab serta berintegrasi sosial. Individu-individu tersebut adalah bagian-bagian dari sebuah lingkungan ekosistem tersebut, 
baik itu orang tua, anak, tetangga, kepala desa, perangkat desa, dan semua warga yang berada dalam ekosistem tersebut. Lingkungan yang kondusif ini cenderung akan membentuk pribadi yang baik seperti lingkungan tersebut.

Lingkungan ini tercermin dari kehidupan sehari-hari Kampung Batik Manding Siberkreasi. Motif-motif batik yang digambar pada dinding-dinding rumah warga memberikan pemahaman bagi anak-anak sekitar untuk mencintai batik sejak dini. Sehingga batik tidak hanya dapat menjadi pembelajaran bagi orang dewasa namun juga bagi generasi yang akan datang.

Keteladanan merupakan unsur paling mutlak untuk melakukan perubahan perilaku hidup. Seoarang ank bahkan dewasa secara psikologis memiliki kemampuan untuk menyerap informasi dan pengaruh dari luar dengan kalkulasi-kalkulasi, pengaruh yang diserap melalui mata sebanyak $84 \%$, melalui telinga $11 \%$, sedangkan factor yang lain $50 \%$. Melalui mata atau keteladanan artinya apa yang dilihat dan disaksikan akan dicontoh, melalui telinga berupa nasihat, tausyiah, saran, pendapat, hanya efektif mengubah perilaku sebanyak 11\% (Sanusi, 2016).

Dari dulu sampai sekarang, proses pendidikan selalu melibatkan minimal tiga pelaku, yaitu sekolah, orang tua dan masyarakat. Tetang tripusat pendidikan ini, Ki Hajar Dewantara (KHD) menganggap bahwa pendidikan yang utama dan pertama adalah orang tua (Koesoema, 2018).

Banyak nilai-nilai yang dapat kita ambil dari batik, dimulai dari prosesya hingga motif-motif yang terkandung di dalamnya. Proses batik sendiri dilakukan sampai Sembilan tahapan, dimulai dari ngemplong hingga nglorod. Proses yang panjang ini memberikan gambaran pada kita pentingnya sikap sabar dan kehati-hatian dalam membatik. Sifat yang terkandung dalam proses membatik ini sangat cocok jika kita kaitkan dengan karakter masyarakat Indonesia saat ini. Dengan mengikuti proses membatik seseorang seharusnya dapat menemukan betapa pentingnya sikap sabar, kehatian-hatian, dan ketelitian dalam prosesnya.

Pendidikan yang tidak didasari oleh kebudayaan akan menghasilkan generasi yang tercerabut dari kehidupan masyarakat sendiri. Menjanjikan pendidikan yang steril dari kekayaan budayanya sendiri, dan berpotensi untuk menghasilkan enclave dalam masyarakat. Kebudayaan yang tidak menyatu dengan pendidikan, akan cenderung asing bago kehidupan dan mulai ditinggalkan oleh masyarakat sendiri (Swasono, 2013)

Motif barik adalah suatu dasar atau pokok dari suatu pola gambar yang merupakan pangkal atau pusat suatu rancangan gambar, sehingga makna dari tanda, simbol, atau lambang dibalik motif batik tersebut dapat diungkap. Motif merupakan susunan terkecil dari gambar atau kerangka gambar atau kerangka gambar pada beda (Wulandari, 2011). Di motif batik terdiri atas unsur bentuk atau objek, skala atau proporsi, dan komposisi. JPSI, Vol. 2, No., 2, 2019 
Motif itu mengalami penyusunan dan diterapkan secara berulang-ulang sehingga terciptalah sebuah pola. Pola yang diterpkan pada benda lain akan menjadi sebuah ornamen. Dibalik kesatuan motif, pola, dan ornament ada banyak pesan dan harapan dari sang pencipta.

Dari sisi motif yang dihasilkan di Kampung Batik Manding Siberkreasi ada beberapa jenis motif seperti, Batik Motif Manding, Motif Selogupito Megar Keri, Motif Jerukwudel, Motif Hargosari, motif Sinuwun, motif Kedung Keris, Motif Krambil Sawit, Motif Cangkring, Motif Babad Alas Nogkodoyo, dan Motif Bedoyo. Motif-motif yang diciptakan oleh warga kampung batik ini sendiri terinspirasi dari daerah daerah di sekitar Gunungkidul. Dan dalam pelaksanaannya batik-batik ini diberikan kepada kampung tempat asal motif itu ditemukan. Batik-batik tadi sendiri memiliki makna-makna sebagai berikut;

1. Batik Manding

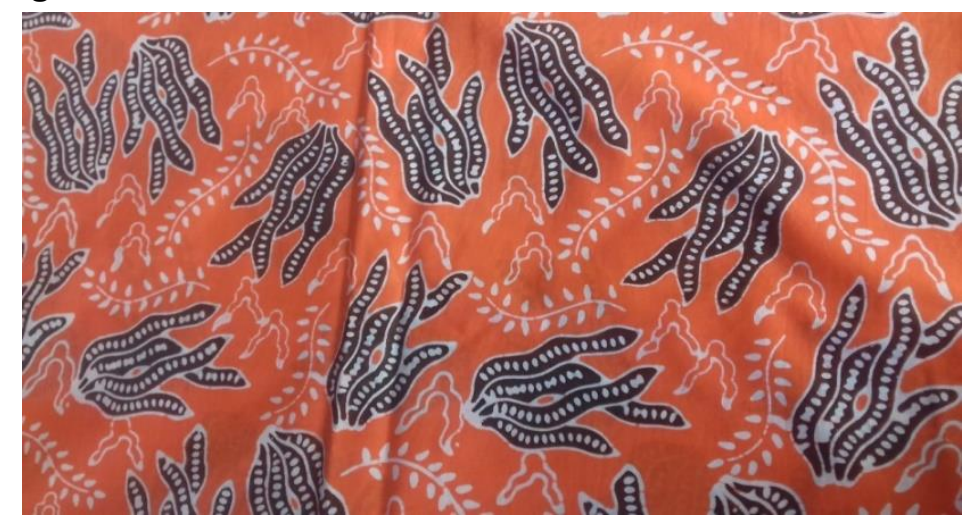

Gambar 1. Batik Motif Manding (dokumentasi pribadi, 2019)

Batik Manding ini berasal dari daerah Kepek, Wonosari. Dari motif yang tergambar sendiri adalah tanaman manding muda yang menandakan semangat dari Desa Kepek yang selalu berjiwa muda dan berkobar. Terdapat juga gambar daun sebagai harapan Desa Kepek tetap subur dan terjaga kelestarian lingkungannya. Serta gambar pegunungan yang gunung disini mengambarkan kekuatan batin masyarakat Gunungkidul yang sulit untuk tergoyahkan, walaupun kondisi alamnya sering kekeringan mereka tetap bertahan dan kreatif memanfaatkan setiap tanaman yang berpotensi pada kondisi tersebut. Dalam sisi spiritual, gunung disini juga dianggap sebagai makro kosmos yaitu kekuatan alam.

JPSI, Vol. 2, No., 2, 2019 
2. Batik Selogupito Megar Keri

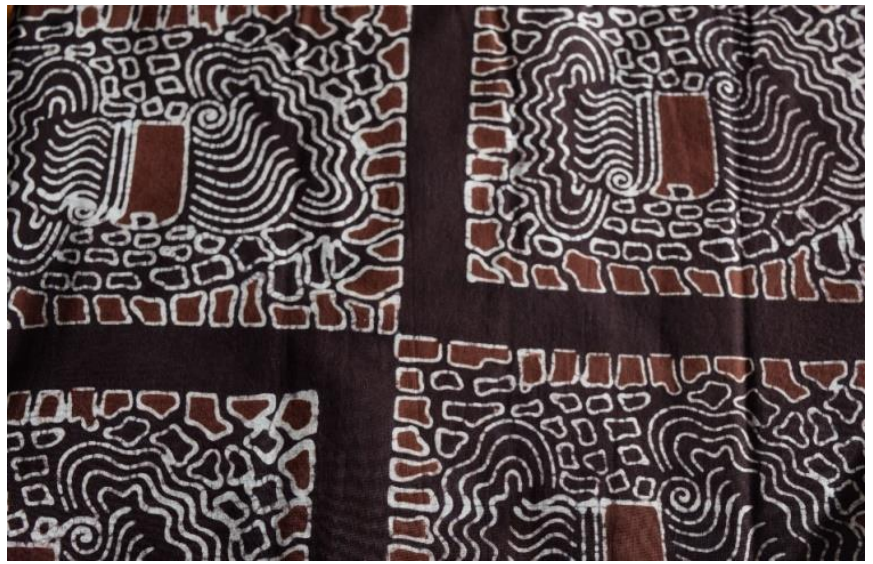

Gambar 2. Batik Motif Selogupito Megar Keri (dokumentasi pribadi, 2019)

Batik Selogupito Megar Keri ini berasal dari Desa Gari yang memiliki arti dalam Bahasa Jawa yaitu kari/ mung atau dalam Bahasa Indonesia di artikan dengan "hanya". Hal ini terkait dengan keadaan kondisi alam dan tanah desa dari Gari yang tandus dan gersang serta penuh dengan bebatuan (selo/tewaton) seperti yang tergambar dalam batik diatas. Hal ini menyebabkan Desa Gari tidak cocok dan sangat tidak produktif jika digunakan sebagai lahan pertanian. Kondisi alam ini tentu saja berdampak pada mata pencaharian masyarakat Desa Gari yang akhirnya pada zaman dahulu mulai memanfaatkan tanah yang tandus tersebut untuk diolah dan diproduksi menjadi genteng.

Masyarakat Desa Gari juga kreatif dan memiliki inisiatif memanfaatkan batu (selo/ tewaton) tersebut untuk ditambang dan diolah menjadi gamping dan diolah menjadi kerajinan batu ukir. Selain bebatuan dalam gambar ini pada bagian tengah juga terlihat jelas gambar aliran air serta sumber mata air yang masyarakat jawa zaman dahulu biasa menyebutnya dengan belik. Belik ini berfungsi sebagai sumber mata air kehidupan pada zaman dahulu. Melalui belik inilah dapat disimpulkan bahwa, walaupun Desa Gari memiliki kondisi alam dan tanah yang tandus dan gersang akan tetapi, tetap ada karunia Tuhan Yang Maha Esa yang patut disyukuri. 
3. Batik Jerukwudel

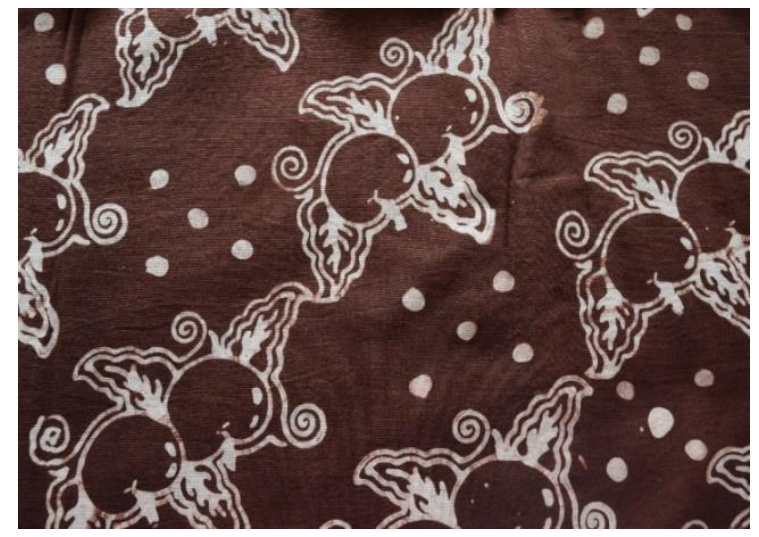

Gambar 3. Batik Motif Jerukwudel (dokumentasi pribadi, 2019)

Batik ini berasal dari Desa Jerukwudel, Girisubo. Nama jerukwudel ini sendiri diambil dari "jeruk", dimana pada awal terbentuknya di desa ini terdapat tanaman jeruk yang sangat manis rasanya. Pada suatu waktu seorang warga bernama "Joko Suro" menemukan buah jeruk yang didalamnya terdapat benjolan seperti wudel bodong, sehingga oleh Joko Suro desa tersebut dinamakan Jerukwudel karena, Joko Suro memiliki kelebihan yang telah diakui oleh masyarakat setempat yaitu dalam hal pengobatan penyakit Pathek, maka masyarakat menyetujui daerah ini dinamakan Jerukwudel.

4. Batik Hargosari

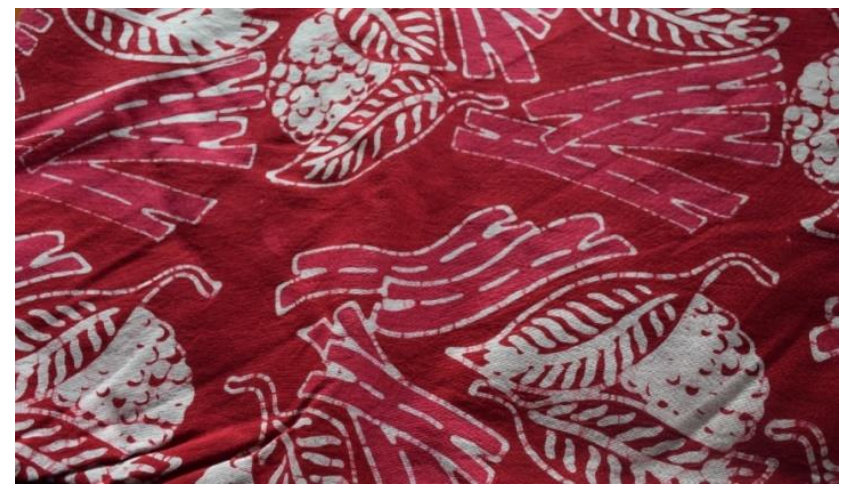

Gambar 4 . Batik Motif Hargosari (dokumentasi pribadi, 2019)

Batik Hargosari ini berasal dari Desa Hargosari, Kecamatan Tanjungsari, Tepus. Di desa ini banyak tumbuh tanaman Srikaya dan ketela sehingga, kedua tanaman ini menjadi ikon dari desa tersebut. Tanaman ini juga diperjualbelikan oleh penduduk setempat untuk 
menambah kesejahteraan dan meningkatkan perekonomian. Tanaman ketela di desa ini juga diolah menjadi manggleng atau krecek untuk menambah cita rasanya.

5. Batik Sinuwun

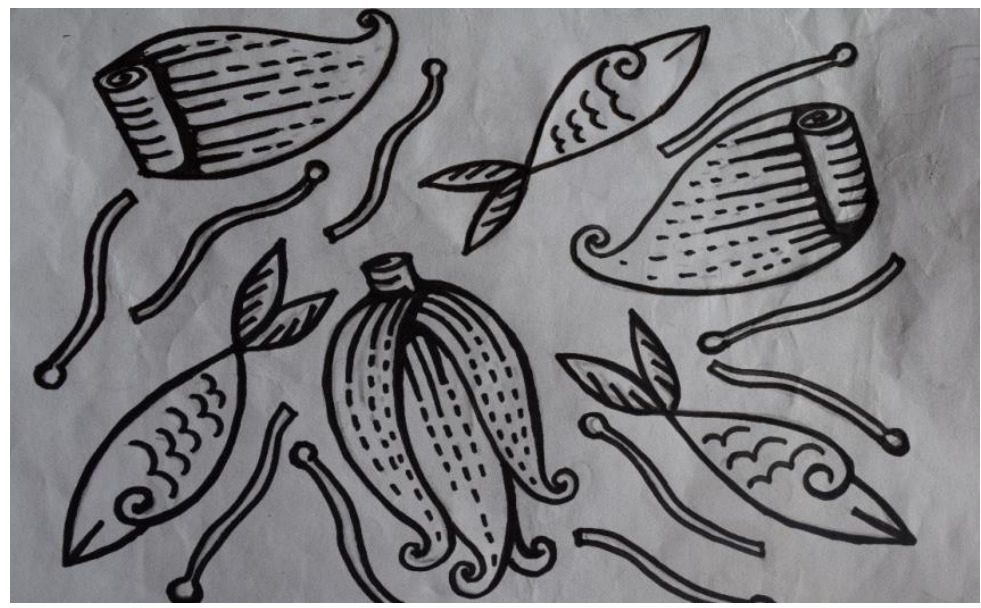

Gambar 1. Batik Motif Sinuwun (dokumentasi pribadi, 2019)

Batik Sinuwun ini berasal dari daerah Jelok, Pathuk. Motif Sinuwun ini terinspirasi dari daerah Jelok sendiri karena, daerah ini banyak menghasilkan jantung pisang dan sungai Oyanya yang juga terkenal sebagai penghasil ikan yang melimpah. Di daerah ini ikan sungai dan jantung pisang diolah menjadi gudeg yang diberi nama dengan gudeg sinuwun. Masakan ini sangatlah khas karena, biasanya gudeg terbuat dari nangka muda dan masakan ini pun tidak ditemui di daerah lain. Hal ini menjadikan daya tarik tersendiri dari daerah ini. Hal ini termasuk kearifan lokal karena, sampai sekarang masyarakatnya masih memanfaatkan bahan- bahan tersebut menjadi olahan yang dapat dinikmati. 
6. Batik Kedung Keris

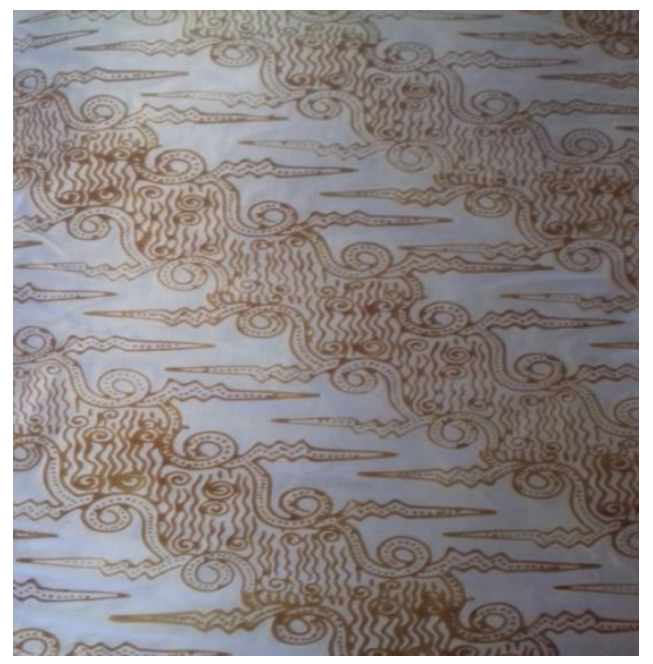

Gambar 6. Batik Motif Kedung Keris (dokumentasi pribadi, 2019)

Kedung berasal dari Bahasa Jawa yang artinya sungai atau lubuk. Sungai yang di maksud adalah sumber kehidupan bagi masyarakat sekitar dan gelombang yang tergambar memberikan makna walapupun, kehidupan naik turun tetapi diharapkan tetap mampu menjadi konsisten dan stabil serta tidak mudah untuk menyerah dan pasrah.

Keris adalah senjata karya sang empu yang dihasilkan selama hidupnya. Dalam hal ini maka keris sebenarnya sudah berada pada beberapa keturunan yang telah menggunakannya. Keris karena memiliki kemampuan yang cukup luar biasa ini, maka ia mampu bertahan hingga diwariskan ke beberapa keturunan yang tentunya sudah berusia ratusan, bahkan bias mencapai ribuan tahun (Pamungkas, 2007).

Disisi lain, keris memiliki makna sebagai kewibawaan. Keris disini mengarah pada pemimpin yang bijaksana. 
7. Batik Krambil Sawit

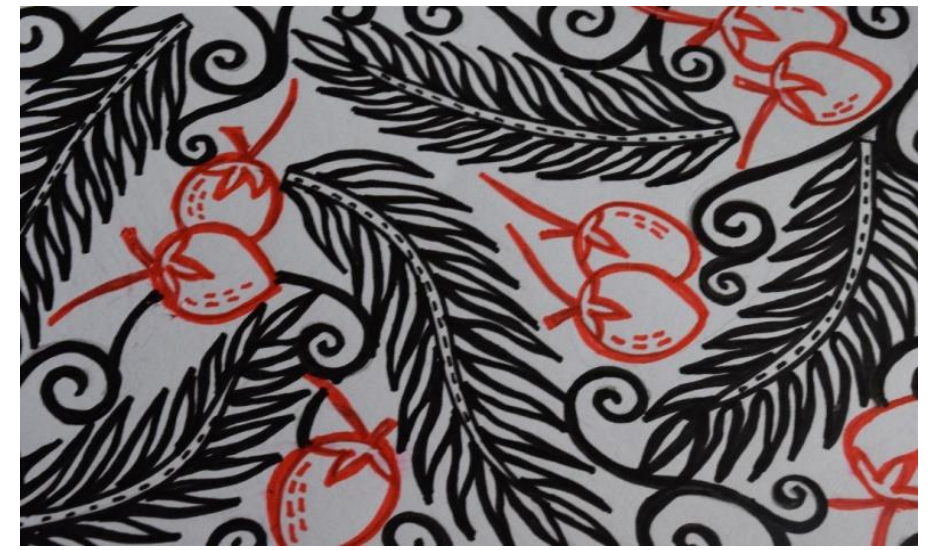

Gambar 1. Batik Motif Krambil Sawit (dokumentasi pribadi, 2019)

Krambil Sawit adalah nama sebuah desa yang terletak di kelurahan Saptosari. Desa ini memiliki keunikan tersendiri yang tidak dimiliki oleh desa lain yaitu dalam desa ini terdapat pohon kelapa yang memiliki 5 cabang. Pohon kelapa inilah yang memberikan inspirasi dari motif batik yang digambarkan. Pohon kelapa ini sendiri sangat bermanfaat bagi masyarakat sekitar yang memang bagian-bagian dari pohon kelapa sendiri dapat dimanfaatkan secara keseluruhan. Pohon kepala 5 cabang ini juga memiliki arti bagaimana hidupmu dapat berguna bagi orang lain disekitar dengan memanfaatkan potensi- potensi yang kamu miliki secara maksimal (5 batang secara keseluruhan).

8. Batik Cangkring

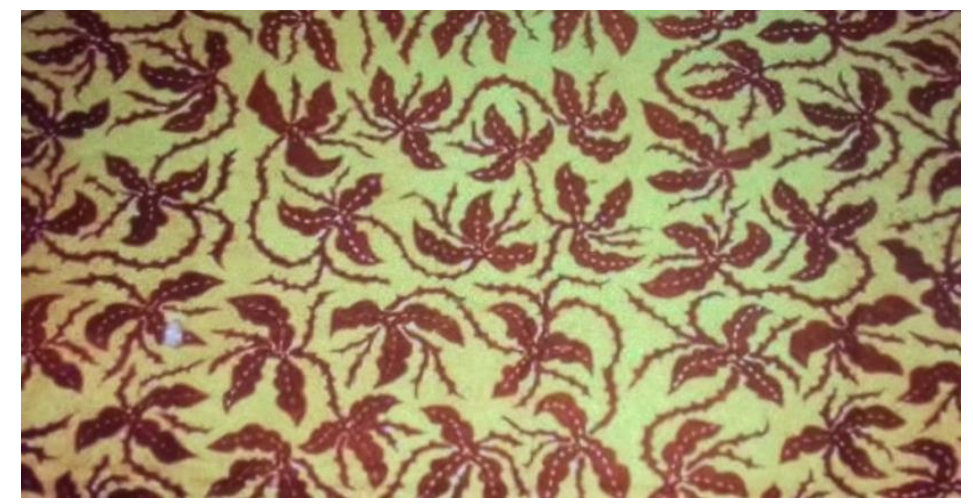

Gambar 8. Batik Motif Cangkring (dokumentasi pribadi, 2019) 
Batik ini berasal dari desa Bansari, Kepek yang sebelumnya dinamakan desa Cangkring. Dinamakan desa cangkring karena, hampir di semua sudut di desa ini ditumbuhi pohong cangkring yang berfungsi sebagai obat cangkrang atau cacar air bagi masyarakat setempat. Tanaman cangkring inilah yang menjadi ikon dari Desa Bansari hingga saat ini. Tanaman cangkring sendiri selain sebagai penyembuh cacar air juga memiliki manfaat lain yaitu sebagai penyembuh demam, cacingan, disentri, melancarkan haid, melancarkan ASI, dsb.

9. Batik Babad Alas Nongkodoyo

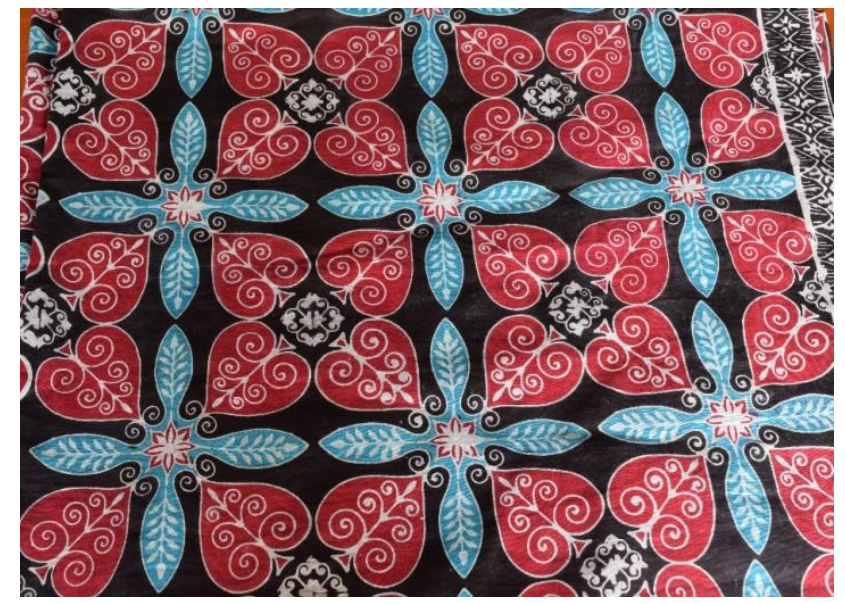

Gambar 9. Batik Motif Babad Alas Nongkdoyo (dokumentasi pribadi, 2019)

Nama Ki Demang Wonopawiro sangat erat hubungannya dengan sejarah berdirinya kota Wonosari atau yang lebih dikenal dengan Babad Alas Nongko Doyong. Menindak lanjuti pembagian wilayah baru Kasultanan Mataram Yogyakarta, yang secara resmi dengan ditetapkannya pembentukan Kabupaten Gunungkidul. Sultan Hamengkubuwono V kemudian mengangkat Raden Tumenggung Prawirosentiko sebagai Adipati Gunungkidul menggantikan KRT Poncodirjo, sekaligus meminta untuk mengatur wilayah Gunungkidul yang khususnya memindahkan kabupaten ke lokasi yang lebih dekat dengan Yogyakarta, tetapi juga dekat dengan semua rakyat di Gunungkidul. Maka dipilihlah hutan Alas Nongko Doyong yang daerahnya datar, sumber airnya juga melimpah, tanahnya subur serta lokasinya strategis. Namun kemudian yang menjadi kendala adalah hutan Alas Nongko Doyong itu terkenal gawat keliwat-liwat, angker kepati-pati. Jalma moro,jalma mati, karena dikuasai oleh Nyi Gadung Mlati. Untuk pelaksanaan perintah pembukaan hutan tersebut Tumenggung Prawirosentiko memerintahkan bawahan kepercayaannya seorang demang dari Piyaman yang bernama Ki Demang Wonopawiro, 
seorang yang sakti, patuh dan berbakti kepada atasan. Ki Demang Wonopawiro melaksanakan tugas mulia sekaligus berat tersebut dengan dibantu oleh Mbok Nitisari (dukun sakti dari Piyaman). Kemudian mereka meminta ijin kepada Nyi Gadung Mlati untuk membuka hutan Alas Nongko Doyong, namun Nyi Gadung Mlati tidak mengijinkan dan terjadilah pertempuran. Ki Demang Wonopawiro diberi senjata tombak Kyai Muntab oleh Mbok Nitisari dan dalam pertempuran tersebut akhirnya Nyi Gadung Mlati kalah dan kemudian mengijinkan pembukaan hutan. Maka dengan mengerahkan rakyat Piyaman dan juga dibantu oleh Nyi Gadung Mlati secara spiritual Ki Demang Wonopawiro melakukan pembukaan hutan Alas Nongko Doyong sebagai kabupaten yang kemudian diberi nama Wonosari oleh Tumenggung Prawirosentiko.

Makna dan Filosofi Motif :

1. Gambar ceplok bunga melati menggambarkan Nyi Gadung Mlati penguasa hutan Alas Nongko Doyong (dalam bahasa jawa sing mbaurekso)

2. Gambar 4 Tombak melintang menggambarkan pusaka Ki Demang Wonopawiro yang melambangkan kewibawaan seorang pemimpin sebagai sipat kandel dalam menjaga dan memelihara suatu wilayah atau daerah. Didalam gambar tombak terdapat ornamen butir-butir padi yang melambangkan kesejahteraan dan kemakmuran. (Gambar melati dan 4 tombak yang melintang tersebut di sisi lain juga mempunyai makna filosofi papat kiblat lima pancer)

3. Gambar Kayon (Nongko Doyong) menggambarkan sebuah wilayah atau daerah, Gambar kayon/daun nangka yang berbentuk jantung hati melambangkan kasih sayang, tresno asih,tepo sliro dan gotong-royong yang merupakan budaya masyarakat Gunungkidul yang sampai saat ini masih terjaga sehingga mampu mewujudkan keharmonisan dalam hidup bermasyarakat.

4. Gambar ornamen sulur didalam kayon yang melingkar-lingkar menggambarkan kelenturan,mentalitas yang kuat dan keuletan masyarakat Gunungkidul yang tetap selalu survive dengan kondisi dan keadaan alamnya. 
10. Batik Bedoyo

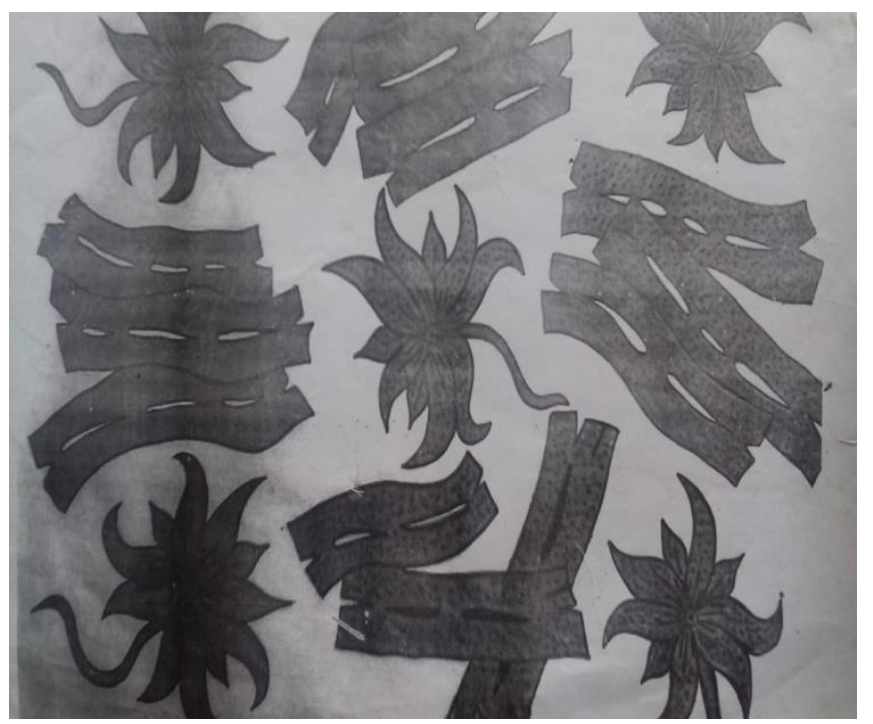

Gambar 10. Batik Motif Bedoyo (dokumentasi pribadi, 2019)

Batik ini berasal dari Bedoyo, Ponjong. Ikon dari batik Bedoyo ini adalah tanaman ketela yang kemudian diolah menjadi manggleng. Tanaman ini adalah tanaman produktifitas dari desa ini dan manggleng merupakan oleh- oleh khas dari desa Bedoyo sendiri. Harapan dari motif ini adalah agar ketela yang telah diolah menjadi manggleng ini dapat menambah kesejahteraan serta meningkatkan perekonomian warga setempat.

\section{SIMPULAN}

Batik merupakan salah satu kebudayaan Nasional Indonesia yang tidak dapat kita pisahkan dari kehidupan bangsa ini. Setiap pola, motif, warna, lekukan dan sejarahnya mengandung nilai-nilai tertentu yang dapat kita ambil pelajarannya. Nilai-nilai ini seharunsya menjadi nilai-nilai karakter yang ditiru oleh masyarakat Indonesia.

Kampung Batik Manding Siberkreasi ini adalah salah satu kampung yang menawarkan pendidikan karakter bagi masyarakatnya terutama anak usia dini. Di kampong ini anak-anak diberikan keteladanan betapa pentingnya untuk nilai-nilai karakter tersebut.

Batik yang dihasilkan dari Kampung ini memiliki nilai-nilai yang sengaja diambil dari ciri khas dan sejarah daerah tersebut. Harapan dan keinginan pencipta batik tertuang di dalam motif batik yang diciptakan. Pembelajaran ini diberikan agar masyarakat dapat memahami betapa pentingnya warisan yang terkandung di dalam Indonesia. 


\section{DAFTAR PUSTAKA}

Darini, R. 2013. Sejarah Kebudayaan Indonesia Masa Hindu Buddha. Yogyakarta: Penerbit Ombak.

Koesoema, D. 2017. Pendidikan Karakter Berbasis Kultur Sekolah: Menumbuhkan Ekosistem Moral Pendidikan. Yogyakarta: Penerbit Kanisius.

Koesoema, D. 2018. Pendidikan Karakter Berbasis Komunitas: Memberdayakan Partisipasi Masyarakat dalam Pendidikan. Yogyakarta: Penerbit Kanisius.

Kusrianto, A. 2013. Batik: Filosofi, Motif \& Kegunaan. Yogyakarta: Penerbit Andi.

Mu'in, F. 2014. Pendidikan karakter: konstruksi teoretik \& praktik. Yogyakarta: Penerbit Ar-Ruzz Media.

Paeni, M. 2009. Sejarah Kebudayaan Indonesia: Seni Rupa dan Desain. Depok: Rajawali Pers.

Pamungkas, R. 2007. Mengenal keris: senjata "magis" masyarakat Jawa. Yogyakarta: Narasi.

Sanusi, A. 2016. Jalan Kebahagiaan. Jakarta: Gema Insani.

Swasono, S. E. 2013. Kebudayaan Mendesain Masa Depan. Yogyakarta: UST Press.

Wulandari, A. 2011. Batik Nusantara: makna filosofis, cara pembuatan \& industri batik. Yogyakarta: Penerbit Andi.

Parmono, K. 2013 Nilai Kearifan Lokal Dalam Batik Tradisional Kawung. Jurnal Filsafat Universitas Gadjah Mada. 23 (2). 1-13. https://jurnal.ugm.ac.id/wisdom/article/view/13217/9459.

Prasetya, S.A. 2016. Karakteristik Motif Batik Kendal Interpretasi dari Wilayah dan Letak Geografis. Jurnal Imajinasi. 10 (1). 51-60. https://journal.unnes.ac.id/nju/index.php/imajinasi/article/view/8816 